This item was submitted to Loughborough's Research Repository by the author.

Items in Figshare are protected by copyright, with all rights reserved, unless otherwise indicated.

\title{
Perspectives of the dropped-out children on their dropping out from public secondary schools in rural Pakistan
}

PLEASE CITE THE PUBLISHED VERSION

https://doi.org/10.1016/j.ijedudev.2019.02.004

PUBLISHER

(C) Elsevier

VERSION

AM (Accepted Manuscript)

\section{PUBLISHER STATEMENT}

This paper was accepted for publication in the journal International Journal of Educational Research and the definitive published version is available at https://doi.org/10.1016/j.ijedudev.2019.02.004

\section{LICENCE}

CC BY-NC-ND 4.0

\section{REPOSITORY RECORD}

Aldridge, Jo, Abdul Mughal, and Mark P. Monaghan. 2019. "Perspectives of the Dropped-out Children on Their Dropping Out from Public Secondary Schools in Rural Pakistan”. figshare. https://hdl.handle.net/2134/36953. 


\title{
Perspectives of Dropped-out Children on their Dropping out from Public Secondary
} Schools in Rural Pakistan

\begin{abstract}
The world can only meet prescribed educational targets of the Sustainable Development Goals (SDGs) if all boys and girls complete free, equitable and quality primary and secondary education by 2030 . However, the problem of dropping out from school is a barrier to such goals in poor and developing countries. In Pakistan, in total, 73\% of children aged 516 (classes 1 to 10) drop out before reaching the final grade of secondary school. It is important to listen to the personal stories of dropped out children in order to design better and more effective policy responses. In this study, 18 secondary school dropped-out boys were interviewed in order to explore the social and cultural contexts around their dropping out and the competing economic, social and family demands placed on them. The findings show that a range of 'push' and 'pull' factors, that operate at individual, family and structural levels and that at times intersect or combine - influence children's willingness and ability to attend school.
\end{abstract}




\section{Introduction}

UNESCO Institute for Statistics (UIS) and the Global Education Monitoring Report (GEM) 2017 estimate that some 61 million children of primary school age (6 to 11 years), 62 million of lower secondary school age (12 to 14 years) and 141 million youth of upper secondary school age (15 to 17 years) are out of school in the world (UNESCO Institute for Statistics (UIS), 2017). This problem is more serious in Sub-Saharan Africa and South Asia. Among South Asian countries, in Pakistan there are currently 5.6 million primary, 5.4 million lower secondary and 9.8 million upper secondary school age children out of school (UNESCO Institute for Statistics (UIS), 2017). Although Pakistan has declared its constitutional responsibility through the Constitution Eighteenth Amendment Act, 2010, to provide free and compulsory education to all children aged five to sixteen (National Assembly of Pakistan, 2012), it bears the second largest number of primary age out-of-school children in the world, after Nigeria (UIS, 2017). For future, the world has committed to achieve free, equitable and quality primary and secondary education by 2030 through Sustainable Development Goals (SDGs) which came into effect in January 2016 (United Nations, 2016). Thus, it is necessary to address the issue of dropping out from primary and secondary education in the poor and low-income countries to ascertain the targets of SDGs.

Out-of-school children are further categorised as 'never enrolled' and 'dropouts'. The problem of dropping out from public schools is serious in Pakistan, particularly in rural areas. School entry age for children is 5 years in the country. According to a 2013 report by the Academy of Educational Planning and Management (AEPAM), out of the total enrolment in Class 1 at age 5, only 63\% progress through primary stages $1-5,40 \%$ progress through elementary school classes $6-8$, and only $27 \%$ to secondary level (AEPAM, 2013). In total, $73 \%$ of children aged 5-16 (classes 1 to 10 ) drop out before reaching the final grade of secondary school. This is one of the highest school dropout rates in the world. Across all levels, the dropout rate is highest at secondary school level (in particular classes 9 and 10), and nearly $14.5 \%$ of children drop out of secondary classes (aged 14 to 16) in rural areas (ASER-Pakistan, 2017). Because of this low completion rate, only $33.2 \%$ of the Pakistani population has some sort of secondary education (UNDP, 2014). In this article, we consider the process of dropping out from school from the perspective of boys who have recently experienced it. The data presented here are drawn from a larger piece of research considering the issue of school dropping out from various perspectives, including teachers and head teachers, school councils, parents and children. We suggest that there are a number of push 
and pull factors which explain the occurrence of dropping out. At various points these dynamics intersect. Our findings are in part consistent with existing explanations of school dropout, but also at times depart from these. The next section considers some of the extant explanations for pupil dropout, we then discuss the methodology behind our approach. Following on we present the various push, pull and interconnected factors to explain the dropout process before offering some concluding remarks and suggestions for further research.

\section{Existing Explanations for School Dropout}

The existing literature on dropping out largely identifies poverty as a leading factor in children finishing school early (Abuya, Oketch, \& Musyoka, 2013; Al-Hroub, 2014; Ampiah \& Adu-Yeboah, 2009; Bridgeland, 2010; Dakwa, Chiome, \& Chabaya, 2014; Hunt, 2008; Moyi, 2012; Munsaka, 2011; Smits \& Huisman, 2013; Stephens, 2000; Yi et al., 2012). Smits and Huisman (2013) investigated household effects and district level factors on primary school enrolment in thirty developing countries. Among other factors, they found that household wealth significantly impacted schooling decisions. Similarly, Yi et al. (2012) conducted a survey study of 46 junior high schools in two provinces in North and Northwest China during 2009-2010 to measure dropout rates. They asserted that students with fewer family assets were more likely to drop out of school. Furthermore, Moyi (2012) studied school enrolment patterns in Somalia and identified that the children from higher socioeconomic households were more likely to attend formal schools than those from lower socioeconomic households.

In addition, some studies reported that for some children gender bias, birth order within a family and having a high number of siblings were the contributing factors to children dropping out of school (e.g., Abuya, Onsomu, \& Moore, 2012; Colclough, Rose, \& Tembon, 2000; Cole \& Bojang, 2002; Huisman \& Smits, 2009; Lloyd, Mete, \& Grant, 2009; Mukherjee \& Das, 2008; Sathar \& Lloyd, 1994; Sawada, 1997; Sawada \& Lokshin, 2009; Siddhu, 2011; Yi et al., 2012). Sathar and Lloyd (1994) maintain that having many siblings causes schooling inequalities where the first-born children have an advantage over younger siblings in rural Pakistan. They further argue that birth order is more significant than the number of siblings in a family. On the other hand, Sawada and Lokshin (2001) report that a greater number of older siblings, particularly sisters can help with the completion of primary schooling for younger siblings as female family members contribute more to the household's 
labour. They also assert, however, that the monetary contribution of older brothers also increases schooling possibilities for the younger siblings at secondary level. Sawada (1997) reported gender bias is visible in schooling decisions in rural Pakistan and Abuya et al. (2012) reported similar bias with girls' perspectives in Nairobi province, Kenya, while Cole and Bojang (2002) found that in rural Gambia sons were given preferential treatment (with regards to their education) compared to daughters.

For Sathar and Lloyd (1994), the number of siblings does not matter as much in rural areas as it does in urban Pakistan at the primary level because of low schooling costs in the former area. However, Huisman and Smits (2009) studied primary school enrolment for 220,000 children in 340 districts of 30 developing countries and their evidence shows that three or more brothers or sisters in a family reduced the enrolment of both sexes regardless they live in rural or urban areas.

In contrast, Gibbs and Heaton (2014) assert that family size has less impact on school dropout at secondary level than at primary level in Mexico. Mukherjee and Das (2008), meanwhile, explored the relationship between parental skills, knowledge and experience (human capital) and financial outcomes of children in terms of their schooling, dropping out and working as labourers in urban India. Siddhu (2011) found similar results in Utter Pradesh, India. Furthermore, these studies revealed that the number of siblings in a family with low financial means has a negative effect on the high school attendance of children, particularly girls (Hu, 2012; Siddhu, 2011; Yi et al., 2012). Contrary to these findings, Colclough et al. (2000) argued that a large number of siblings distributed household work equally, which benefitted girls' education because they had fewer chores to do. Rosati and Rossi (2003) showed similar results in Pakistan and Nicaragua, arguing that large family size had a negative effect on children's working hours, which ultimately benefitted their schooling.

The existing literature also largely establishes parental educational level as a determinant of children completing schooling (see, Andrabi, Das, \& Khwaja, 2008; Bilquees \& Saqib, 2004; Gibbs \& Heaton, 2014; Hazarika, 2001; Holmes, 2003; Lloyd et al., 2009; Mukherjee \& Das, 2008; No, Sam, \& Hirakawa, 2012; Sathar \& Lloyd, 1994; Sawada \& Lokshin, 2001; Smits \& Huisman, 2013; Yi et al., 2012). However, these authors are divided with respect to arguments about the impact of parents' education on their children's schooling, how much this influences girls' and boys' schooling, and whether it helps more at 
primary or secondary level. It is generally presumed that the children of less-educated parents are more likely to drop out of school (Gibbs \& Heaton, 2014) whereas the children with educated parents are more likely to complete schooling (No et al., 2012). Usually, the probability of dropping out significantly decreases if the mother has attended school: this impacts girls more than boys in rural Pakistan (Andrabi et al., 2008; Hazarika, 2001; Holmes, 2003; Lloyd et al., 2009; Sathar \& Lloyd, 1994). Huisman and Smits (2009) also corroborate these findings by presenting evidence from 30 developing countries that shows the mother's education has a significant effect on primary school enrolment. On the other hand, Sawada and Lokshin (2001) argue that both the father's and mother's education are significant in children's primary and elementary schooling in rural Pakistan. Nevertheless, they stated that parental education is insignificant in relation to dropout rates from secondary schools. Gibbs and Heaton (2014) argue that the mother's education matters less in preventing school dropouts at the secondary level in Mexico. On the other hand, some studies argue that the mother's education is a more significant factor in completing secondary education (e.g., $\mathrm{Hu}$, 2012; Mukherjee \& Das, 2008). There is little consensus in these studies as to how a father, or a mother with primary, elementary or even with secondary education, can provide study support to their children at an advanced stage.

Grade repetition is also a prominent contributory factor in the dropping out of school (e.g., Grissom \& Shepard, 1989; Jimerson, Anderson, \& Whipple, 2002; Motala, Dieltiens, \& Sayed, 2009; Stearns, Moller, Blau, \& Potochnick, 2007). Grissom and Shepard (1989) argued that retention in the same class causes dropping out from high school regardless of the socioeconomic status of the students. They further maintained that retention results in students becoming discouraged and failing, which ultimately affects their further progression and reinforces their decisions to drop out. In their systematic review of 17 studies specifically addressing association between high school dropout and grade retention, Jimerson et al. (2002) established grade retention as the strongest predictor of students dropping out from high school. In their review, all 17 studies showed that grade retention was linked to later dropout behaviour.

A large number of studies also report that the inability to pay for travel to schools that are at a considerable distance from home caused pupil dropout, particularly among girls (Ali, Hussain, Khan, Rafiqullah, \& Rehman, 2012; Bilquees \& Saqib, 2004; Chugh, 2011; Holmes, 2003; Hunt, 2008; Hussain, Salfi, \& Khan, 2011; Khan, Tahir, \& Shah, 2011; Seidu $\&$ Adzahlie-Mensah, 2010). The cost of travelling long distances places extra burden on poor 
families, so they avoid sending their children to school in these instances. Seidu and Adzahlie-Mensah (2010) highlighted teachers' views that travelling long distances to schools in rural Ghana was causing some children to drop out of school. Similarly, Bilquees and Saqib (2004) reported that travelling any more than $2 \mathrm{~km}$ to school affected poor girls' schooling in urban Pakistan. However, Holmes (2003) found that the distance does not affect primary schooling, only middle and high school attendance for both sexes in rural Pakistan. This is perhaps because young adult girls who cannot afford transportation cost are reluctant to walk long distance schools because of safety and cultural issues prevailed in the remote rural areas (Mughal \& Aldridge, 2017). Similarly, poor boys will also suffer if middle and high schools are far from a village and it is not possible to access them on foot.

Hunt (2008) argues that the existing literature on out-of-school children focuses on identifying push and pull factors of dropping out from school but fails to identify "the processes around dropping out, the personal stories of the children, household members and teachers, their social contexts and the competing demands on them". Mughal and Aldridge (2017) also note this from Mughal's research with female teachers and head teachers (Mughal, forthcoming, 2019). Mughal's findings confirm that the need to travel long distances to attend schools causes many girls to drop out from secondary classes in rural Pakistan. However, the perspectives of dropped out children and their individual stories about withdrawing from school are largely missing in the existing literature and this is particularly evident in the context of Pakistan.

\section{Research Methodology}

This study is one of very first to report individual stories and perspectives of secondary school dropped out children in Pakistan. These voices have hitherto been largely absent from research into the issue of school dropout. To address this gap in the existing literature, Jhelum, a rural district in Punjab, Pakistan, was chosen for the fieldwork. Dropout rates at secondary level stood at $14.5 \%$ in 2014 in Jhelum, which reflected the same national and provincial trends at this level (ASER-Pakistan, 2014). This district was therefore selected as a case study to investigate children's reasons for dropping out of secondary level education from their own perspectives.

Data on dropout rates were collected from 33 public secondary schools (17 for girls and 16 for boys) in subdivision Pind Dadan Khan, a remote rural locality in the district of Jhelum. These schools reported that 741 boys (393 from class 9 and 348 from class 10) and 
103 girls (68 from class 9 and 35 from class 10) dropped out of school during the academic years 2011-12 and 2012-13. The dropped out students never returned to school. Eighteen boys who dropped out from secondary classes were interviewed individually. They were all under the age of 18. The researcher could not recruit any dropped out girls for the study because of cultural constraints in the remote areas of Jhelum.

To summarise, the literature on school dropout generally looks into the problem through the broad lenses of demand and supply (Hunt, 2008), push-out/pull-out factors (Jordan, Lara, \& McPartland, 1996) and the opportunity cost of schooling and rates of return to education (Becker, 1994). Generally, demand factors are linked to individual and family characteristics, whereas supply factors are external ones relating to school and community. Similarly, push-out factors are associated with the school environment and pull-out ascribe to outside social pressures conflicting with educational objectives. Furthermore, Lee and Breen (2007) examined the high school dropout phenomenon through implicit and explicit exclusion. They argued that 'explicit exclusion was identified when the participants were asked to leave or were "kicked out". The more insidious exclusion is implicit, when the participants were isolated and ostracized' (Lee \& Breen, 2007, p. 336). This study explores the process and social contexts of dropping out and individual stories of dropped out pupils. It uses a push-out and pull-out analytical framework to established how school environment and external social pressures cause dropping out.

The real names of the respondents have been changed (pseudonyms are used) to protect their identities. The research was conducted in 33 public high schools situated in rural locations in Punjab. The pupil dropout data obtained from schools was for the academic years 2011-12 and 2012-13. The respondents dropped out either from class 9 or class 10 from those schools during the given academic years. Also, those pupils whose dropping out period did not exceed two years were included in the study. The findings relate to one rural district of Punjab, (Jhelum) and are not generalised to other districts.

The respondents were approached through their teachers and parents. For data collection, a semi-structured interview method was applied. Field work was conducted by the first author. For all interviews, the following guidelines suggested by Bryman (2016) were followed. These includedordering and altering the questions for an easy flow of information, using language relevant to interviewees, asking general biographical information about participants to know their gender, age and experience, becoming familiar with interview 
settings, preparing for questions interviewees may ask during or after the interview, discussing with the participants the most appropriate place for the interviews to take place in a quiet location - and possessing a good quality recording device. The interviews with dropped out boys lasted between 40 minutes to one hour.

Some interviews with dropped out children were held at their workplaces such as shops and bus stands. Nevertheless, in the former case the researcher realised that shop owners regularly interrupted the interview process and so, in order to assure the accuracy of data, he had to change his strategy of interviewing such children at their workplaces. He negotiated meeting with them during their free times and in a quiet separate public place or at their homes. Thematic analysis was used to identify common themes across the data. Because of the small sample size, manual coding was used to organise and arrange themes. All research ethics were fully considered and observed during the entire research process informed consent, right to withdraw from the study, ensuring confidentiality and anonymity (note: the research was validated by the Loughborough University Research Ethics Committee).

\section{Results and Discussion}

There is no universal or unanimous definition of school dropout (Natriello, 1987). This is highly a contextual concept. A child may stop schooling for a certain period or never return to school. If he/she is willing to resume schooling sometime in the future, there is some debate as to whether this would be called dropout or not, not least because of questions about whether resumption of schooling following drop out can be guaranteed. With these complexities in mind, Bjerk (2012) argues, “...defining dropouts can be difficult, as many students leave and return to school multiple times. This is certainly a complicated issue when studying dropouts" (Bjerk, 2012, pp. 112-113).

Pakistan is constitutionally responsible to educate all children aged 5 to 16 years. In which case, any child enrolled onto a formal schooling system and who dropped out before reaching the final grade of secondary education, or who participated in the secondary school exam but failed and left the school without passing the exam, will be defined as dropped out in this study.

\section{Reasons for Dropping out: Perspectives of Dropped out Boys}


Out of the 18 dropped out pupils, 15 lived in the most remote rural areas. Such areas are sparsely populated and far from the main villages. Out of them, 12 dropped out from class 9 and the other six from class 10. They were all schooled in public institutions from class 1 to secondary schooling. None of them had ever enrolled in other forms of schooling such as a private English medium school, a Madrasah or any vocational institution for a short course. They offered different perspectives on dropping out by narrating their individual stories and that are reflected and can be summarised in both push and pull factors (see Hunt, 2008).

Out of the 18 respondents, 13 reported that they dropped out from secondary classes because they were unable to meet the standards of secondary education. Among those 13, seven said that they failed in class 9 and so abandoned their education; on the other hand, three stated that they progressed to class 10 despite failing some subjects in class 9 but, again, they could not pass the combined board examination. The remaining three reported that they did not attend the board exams and discontinued schooling during the academic year. These can all be characterised as push factors for school dropout as they are rooted in systemic failings that force children to drop out of school as a result of education policies and procedures that do not support children effectively, including those who are struggling academically.

Five out of the 18 respondents stated that they dropped out of secondary school because of their family's financial problems. In addition, having a large number of siblings appeared to be a common phenomenon in families in the remote rural areas of the district of Jhelum and which also had a negative impact on children's schooling (both pull factors). Out of the 18 dropout interviewees, for example, 12 had more than five and four had more than three siblings. Two were only children. They all reported that some of their siblings and, in a few cases, all of them had completed secondary schooling. However, seven of them also reported that they had one or two siblings who had previously dropped out of school.

The next section discusses the main reasons for dropping out from secondary classes according to the children's own perspectives and with reference to school related (push) factors; household and family (pull) dynamics; and intersecting push and pull factors.

\section{School related (push) factors}

\section{Poor Educational Background}


The academic mediation theory of pupil dropout confirms that poor educational background is one of the main predictors of dropping out of high school (Battin-Pearson et al., 2000). In this study, out of the 18 respondents, 13 reported that they dropped out of secondary classes because of their previous poor schooling. When they were asked to give reasons for their poor educational background, some argued that they had not studied very well during their primary and elementary education; others blamed the teachers and argued that they had not been taught properly during early classes. There are a number of possible reasons for children's lack of interest in or disengagement from early years education, for example, poor pedagogical skills in the classroom, lack of appropriate facilities at school, lack of extracurricular and sport activities, high pupil-to-teacher ratio, lack of teachers, socio-culturally incompatible syllabus and some ineffective public policies may have a negative impact on children's ability to concentrate in class (Mughal \& Aldridge, 2017). In this study, six of the children reported that poor teaching quality in early classes contributed to their poor educational background and it was this that pushed them out of school in later classes. This was particularly the case in subjects such as English and Science. Azhar, a class 9 dropout reported:

When our elementary English teacher delivered lessons to us, he always held the English syllabus book in one hand and its translation in the other. He would read one English sentence from the course book and looked for its translation from the helping book. He was not able to explain English lessons without looking at the helping book. He looked like reading news rather than teaching the class.

Similarly, another class 9 dropout, Abass, stated:

Our science teacher in elementary classes was not able to explain some scientific terminologies. We just used to learn our science lessons by heart without understanding them. Our teachers remained busy in gossiping with each other at school and gave less attention to teaching.

Other children recalled similar experiences regarding teaching quality during primary and elementary classes. They complained about poor quality teaching specifically at public schools in remote rural areas. This is confirmed in evidence from the head teachers who took part in the study who also expressed concern about the shortage of subject specialists at secondary schools in remote areas. They recognised that qualified teachers preferred to work 
in cities because of better health, education and transportation facilities in urban areas compared to those in rural regions. The result is that primary school teachers often teach both elementary and secondary classes in some schools in rural areas of Punjab, Pakistan (see Mughal and Aldridge, 2017). The findings from this study suggest that poor quality teaching in elementary classes has a negative impact on secondary school education provision. However, UNICEF (2000) emphasises that it is not only the quality of teaching but also the overall quality of education at early stages that help children to progress and complete secondary schooling. According to UNICEF (2000, pp. 5-19) good quality education is linked to a range of quality indicators for learning such as good health and nutrition; early childhood psychosocial development experiences; regular attendance for learning and family support for learning. Similarly, a good quality learning environment includes decent school facilities; class size and peaceful and safe environments, especially for girls; teachers' behaviour and approach to discipline; effective school discipline policies, and inclusive environments.

Over-crowded classes also contribute to poor educational performance. Pupil classroom ratio (PCR) is commonly used as an indicator to measure the quality of education provision. This ratio was 49 pupils per 1 teacher for secondary classes in Punjab in 20142015 (AEPAM, 2017). Mughal and Aldridge (2017) reported that this ratio was 1:70 in some rural areas of Punjab. The lack of a good quality learning environment at public schools in remote rural areas also had an adverse impact on the educational performance of some dropped out pupils who participated in this study. A large number of schools in small villages are lacking in appropriate facilities. Pakistan Education Statistics (2015-16) show that 10,152 primary, 496 elementary and 173 high schools in the public sector do not have appropriate building facilities; 52,659 primary, 3506 middle and 938 high schools are without electricity and there is no clean drinking water facility in 37,079 primary, 2640 middle and 817 high schools in rural Pakistan (AEPAM, 2017). The lack of such basic facilities not only has a negative impact on the learning environment, but it also contributes to poor working conditions which consequently affect teachers' ability to provide good quality teaching (UNICEF, 2013).

Evidence from UNICEF (2000) shows that a good quality and effective teaching and learning environment should include a student-centred, non-discriminatory, standards-based curriculum and effective teaching practices that include professional learning opportunities for teachers; teacher competence and school efficiency; ongoing professional development; 
teachers' beliefs that all students can learn; teachers' working conditions; administrative support and leadership; and the languages schools use for instruction (UNICEF, 2000). It is evident that there is dearth of these quality indicators in schools and in education generally in rural Pakistan.

\section{Poor Health and Malnutrition of School Children}

A further indicator in terms of children's development and capacity to learn is good health and nutrition, but a recent report from the World Food Programme (WFP) shows that the malnutrition of mothers or babies causes the death of more than 1.77 million children under the age of five every year in Pakistan (Word Food Programme (WFP), 2017). Malik (2016) also corroborates that, "Nearly half of all children in Pakistan are chronically malnourished (stunted) while 11 per cent are acutely malnourished (wasted)".

The widespread problem of malnutrition puts children at risk of underperforming and undermines their mental and physical growth. Furthermore, Bhutta (2017) describes the problem of malnutrition in Pakistan:

According to the National Nutrition Survey 2011, one-third of all children are underweight, nearly $44 \mathrm{pc}$ are stunted, $15 \mathrm{pc}$ are wasted, half of them are anaemic and almost one-third of these children have iron deficiency anaemia. These rates have hardly changed over two decades, according to the findings of a maternal and child nutrition study group published by The Lancet in 2013. Notable differences can be found between the nutritional indicators of urban and rural populations; children among the rural and urban poor are at greatest risk. (Daily Dawn, February 10, 2017)

This was evidenced in our study by Muzzafar, aged 10, who had dropped out of school. He said:

I failed in class 10 and did not have the board fee to retake the exam. My eye sight was weak which affected my studies. My family could not afford medical treatment.

In this case Muzzafar's poor eyesight contributed to his poor performance in school and ultimately his dropping out altogether. He said that he never saw a doctor about his poor eyesight because his family could not afford to pay for this and this is often the case in families in more rural areas of Pakistan. Here we can see how systemic factors such as poor education provision - including the lack of nutritional meals provided to pupils while attending school - along with the effects of low income and poverty that affect so many 
families in rural areas of Pakistan, intersect and contribute to children being forced or 'pushed' out of school (these have also been described as implicit factors in dropping out; see Lee \& Breen, 2007).

\section{Poor/Ineffective School and National Education Policies}

Sometimes ineffective policies and practices at local and national level also contribute to poor academic performance and subsequent dropout. For example, as Mughal and Aldridge (2017, p. 15) reported, through the perspectives of teachers and head teachers:

...Government policies of introducing an English-medium syllabus, using teachers as community motivators during school time, putting teachers under unnecessary monitoring, demanding needless paperwork, linking promotion and increments with school results, and introducing capricious examination systems, not permitting class 9 failures to repeat the same class, are all contributing to the dropout problem at secondary level in rural Punjab.

Similar themes are evidenced in Rahmat's story (in the current study), who dropped out of Class 10:

I lost my interest in studies during primary classes as I know that I would get pass regardless I work hard or not. I had no fear of failing. I had no fear of teachers. The teachers did not teach us very well because they knew that they would promote everyone to the next class regardless whether I pass or fail.

Evidence from the pupils who took part also showed that the use of the English medium syllabus at secondary level was causing them to dropout from school. The dropped-out boys recalled their experiences of the difficulties of English language learning and the automatic progression policy in early classes. At the time the research was conducted, the government of Punjab had put an end to the use of corporal punishment and had introduced a nonderegistration policy for absentee pupils at public schools. Indeed, each school had a billboard beside the main gate advertising the "Mar Nahi - Payar" campaign: "No corporal punishment but love"). Some dropped out pupils acknowledged that the combination of the automatic progression policy in early classes and their lack of fear of physical punishment from teachers in the classroom contributed to their poor academic performance and subsequent dropping out from secondary classes. Three of the dropped out boys said that they intentionally remained absent from the school for a long period of time on many occasions 
because they knew that they would not be deregistered from the class. Thus, such policies may help the government to keep the maximum number of students on register; however, they are also contributing to poor educational outcomes and high dropout rates among secondary school pupils.

\section{Failure in Class 9}

The respondents largely reported that failing in class 9 was also a barrier to progression through secondary school. It is evident that failing in class 9 is a widespread problem across Punjab. This evidence is supported by data from the largest examination board in Punjab, the Board of Intermediate and Secondary Education (BISE) Gujranwala.

Table 1 presents the annual results of class 9 examinations in the last five years at BISE Gujranwala.

Table 1. Class 9 Annual Examination Results for the last Five Years

\begin{tabular}{|l|l|l|l|l|}
\hline Year & Applied & Appeared & Passed & Pass Percentage \\
\hline 2012 & 225031 & 221023 & 88649 & 40.11 \\
\hline 2013 & 213547 & 207883 & 79200 & 38.09 \\
\hline 2014 & 243128 & 240088 & 87334 & 36.38 \\
\hline 2015 & 252548 & 248537 & 100857 & 40.58 \\
\hline 2016 & 244454 & 240105 & 129670 & 54.01 \\
\hline
\end{tabular}

Source: BISE-Gujranwala, 2016

The table shows that $45.99 \%$ students in $2016,59.42 \%$ in $2015,63.62 \%$ in $2014,61.91 \%$ in 2013, and 59.89\% in 2012 failed in class 9 annual examinations at BISE Gujranwala. This failure is an indication that most students are unable to complete the secondary school certificate.

Out of the 18 respondents who took part in this study, eight failed in class 9. These children reported that when they failed in class 9, they were not allowed to re-sit in the same class; rather it was mandatory for them to join class 10 . They were then required to re-sit the subjects they had failed in class 9 while at the same time taking the class 10 annual examinations. These students, who already had weak academic backgrounds, could not cope 
with studying both class 9 and 10 subjects together, and thus often dropped out of school. For example, Akbar, who failed in the combined board examination of classes 9 and 10, said:

I failed in four subjects in class 9 but I was forced to sit in class 10 rather than repeating it. It was difficult for me to prepare the failed subjects of class 9 and study the new subjects of class 10. Consequently, I again failed in board exam and never returned to school.

Anees, another dropout who failed in classes 9 and 10 stated that the syllabus in secondary school was difficult for him. Billal also reported that he failed five subjects out of eight in class 9 and again four subjects in the combined examination. Akbar, Anees and Bilal dropped out of school after failing in the secondary education board exams of classes 9 and 10. It is evident here that children with poor educational backgrounds are less able to progress in secondary classes. It further implies that they may need some extra time to adjust to the curriculum at secondary level. The respondents mostly complained about the difficult syllabus, the inability of their families to pay board examination fees and the pressure of the combined examination.

The findings of this study imply that retaining underperforming students in the same class rather than promoting them to the next class may help them with their academic difficulties. Eight of the respondents reported that they found secondary classes difficult; three of them stated that progression to class 10 , despite having failed some subjects in class 9, further affected their performance. Thus, promoting low-achieving pupils of class 9 to class 10 caused some to drop out of secondary education. The existing literature on school dropout has given less attention to the benefits of retention. In a rare exception, Jimerson (2001, p. 434) reviewed research published between 1990 and 1999 to examine the effectiveness of grade retention on academic achievement and socioemotional adjustment and concluded:

Specifically, studies examining the efficacy of grade retention on academic achievement and socioemotional adjustment that have been published during the past decade report results that are consistent with the converging evidence and conclusions of research from earlier in the century that fail to demonstrate that grade retention provides greater benefits to students with academic or adjustment difficulties than does promotion to the next grade. 


\section{Household and Family Dynamics (Pull) Factors}

\section{Home Learning Environment}

Family support for learning is another (pull) contributory factor that shapes children's ability to learn. When the respondents were asked about family support with their schooling, they reported that they had little or no assistance with their school work at home. For example, Raza who dropped out from class 9 stated:

When I entered class 9, I found science subjects difficult. I could not afford private tuition like some other students. None of my family members was enough educated to help me in studies. Our science teacher was running his own private tuition centre out of school hours. He would provide extra study support to only those students who could afford his private tuition fee.

It is clear that private tutoring widens the educational gap between those who can afford to pay for it and those who cannot (UNESCO, 2017). Nath (2008) observed that primary school pupils who receive supplementary tuition learn more than those who do not have access to such support in Bangladesh. He further noted that the demand for supplementary tutoring was higher among children of educated parents and wealthy families. The findings from this study also showed that disadvantaged students with poor educational backgrounds drop out of secondary classes if they have no study support at home or their parents cannot afford private supplementary tuition for them.

Thirteen respondents reported that their family members had never helped them with their homework. They said that their parents and siblings had less or no schooling and that in some cases, because their parents were working in big cities, they were not able to extend study support at home because they did not have the time for this. It is thus evident that the absence of a supportive educational environment at home discourages some children from continuing schooling.

Previous studies have shown that parental education level is a strong predictor in whether children complete their education (e.g., Andrabi, Das, \& Khwaja, 2008; Bilquees \& Saqib, 2004; Gibbs \& Heaton, 2014; Hazarika, 2001; Holmes, 2003; No, Sam, \& Hirakawa, 2012; Sathar \& Lloyd, 1994; Smits \& Huisman, 2013; Yi et al., 2012). In this study, 15 respondents stated that their fathers had completed primary schooling and 13 said that their mothers had no formal education. None of the respondents reported that their mother had 
ever completed secondary education and only three of them had fathers who had received secondary education schooling. Furthermore, only five said that their mothers had completed primary school. Even so, children with mothers with primary education and fathers with secondary education were also found to have dropped out. Similarly, children with siblings who had completed secondary education were also found to have dropped out. This finding is consistent with Sawada and Lokshin's (2001) research that showed that parental education is insignificant in relation to dropout rates from secondary schools.

Furthermore, according to Hornby and Lafaele (2011), parents who demonstrated home-based involvement were those who helped their children with their homework and actively discussed their education with them. In school-based involvement, parents meet with teachers, participate in school activities and respond to any concerns raised by teachers regarding their children's schooling. The dropped out boys who participated in this study said that they had not received any home-based or school-based learning support from their parents. They further reported that parents were not able to provide study support as they were either less educated or not educated at all.

\section{Family Size and Structure - Large number of Siblings}

In the current study, out of the 18 respondents, 12 had more than five and four had more than three siblings. Only two dropouts were only children. The children who had more than five siblings reported financial hardships in their families because there were too many mouths to feed and money was urgently needed from someone who was engaged in paid work. For example, Abbas, a class 9 dropout, reported that he had eight siblings and that his father had died the previous year. His elder brother completed secondary schooling and was serving in the army, but his income was not enough to meet family needs. Abbas was the second male child in the family. He took the responsibility for contributing to the household income and dropped out of school in order to work full time. In Abbas's case, his father's death and the fact that he had a large number of siblings were the two main factors that pulled him out of school. This is consistent with findings from other studies that argue that family size significantly impacts school dropout rates, and increases the chances of child labour $(\mathrm{Hu}$, 2012; Mukherjee \& Das, 2008; Siddhu, 2011; Yi et al., 2012). Abbas further reported that he had two older sisters, but they did not go out to work because of cultural barriers. In this case, it is evident that in a large family when cultural constraints prevent girls from going out to 
work, boys may drop out of school to engage in paid work thus supplementing the family's income.

It is important to note that the children who said they dropped out because of large family sizes had more sisters than brothers. While reporting their families' financial hardships, they noted the pressure of buying Jahez (dowry) to arrange an honourable marriage for their sisters. Jahez is a cultural practice in rural Punjab where a bride brings ornaments, clothes, furniture and all the other common household items to her husband when they marry. This study shows that the number of older sisters adds to the family's financial stress when they reach marrying age. The financial pressure on families of buying dowry for daughters often means the younger brothers are forced to drop out of school, and particularly when they are of secondary school age. This evidence contradicts Sawada and Lokshin's household survey study in Pakistan (2001) that found that a higher number of older sisters in a family enhances schooling opportunities for their younger siblings at primary level because they share the domestic labour. At secondary level, the survey also found that a higher number of older brothers increases the schooling prospects of younger siblings compared with the number of older sisters in a family. This study furthers Sawada and Lokshin's findings and shows that in a rural context when older sisters face cultural barriers with respect to going out to work; it is often younger brothers who take on the financial burdens of a large family. They often dropout of secondary classes to earn money for the family as is evidenced in Sajid's (a class 10 dropout) account:

I have six siblings, two brothers and four sisters. My three sisters have reached to marriage age. I am the fourth child in my family. I got one brother and two sisters older than me. My elder brother who was the main contributor to family income got married recently and started living separately. My father is an old man and works at a local kiln. His income is not enough to buy dowry for the daughters. I quitted school and started working to contribute to family income to arrange wedding for my sisters.

\section{Poverty}

Dropping out of school is largely associated with household poverty - a pull out factor but which has its roots in structural inequalities, meaning that children often have little choice but to dropout of school because their families cannot afford to send them or because children are needed to contribute to household incomes (in this way poverty and low income can be identified as both pull and push out factors). As Kaplan and Luck (1977) argue, "The 
dropout phenomenon is fundamentally rooted in the material and intangible conditions of poverty" (p. 45). Poverty is a widespread phenomenon in Pakistan. According to the Human Development Report 2014, the value of Human Development Index (HDI) is 0.537, which ranks it at 146th position among 187 countries. Out of the total population, $45.59 \%$ people are living in multidimensional and $26.46 \%$ in severe poverty. The portion of population living under $1.25 \$$ a day is $21.04 \%$. The share of working poor who are earning less than $2 \$$ on daily basis is $57 \%$ (UNDP, 2014). In this study, household poverty was a key determinant in children dropping out from secondary school. A number of the children who took part who had dropped out of school cited family financial problems for this. Some said that it was essential they contributed to the household income otherwise the family would not have survived. Out of the 18 respondents, five reported that they left secondary education unfinished because of household poverty. For example, Shabir, a class 9 dropout, who was working on a tea stall, stated:

My father is a street vendor who sells small household items on his bicycle. His income is not enough to meet family needs. We do not have a steady and regular source of income. I would notice that my mother was usually borrowing money from neighbours to pay the electricity bill and sometimes to buy food items for us. It was hard for me to continue schooling in such poor conditions. I was the eldest son and decided to leave school to earn money. I am earning Rs. 5000 (\$50) a month and giving it to my mother.

Asif, who dropped out from class 9 in order to work so that he could pay for medicines for his sick mother, was working as a bus conductor and earning Rs. 8000 (\$80) a month. He said:

When my father was alive our economic conditions were not good. My father was not able to buy me new uniform and shoes for school. I used to wear my cousins' used uniforms and shoes. My family hardly met my educational needs at school. After the death of our father, we were totally depending on our relatives for daily needs. As the financial support from the relatives squeezed, I had to take responsibility being the eldest sibling.

Similarly, Akbar another class 10 dropout who was also working as a conductor with a local passenger van, stated: 
I am earning Rs. 9000 (\$90) a month. I give this money to my mother to run the kitchen. Without my monetary contribution, it is not possible to meet monthly household expenses.

Mateen, a secondary school dropout, was grazing his cow at the foot of the mountains in a remote village. He told his story of dropping out:

I dropped out of school because of our household poverty. My elder brother was dropped out from secondary education for the same reasons. Our parents are not able to afford our secondary schooling. I am grazing this cow. We will sell it next year to earn some profit. This is our family business. We graze cattle for one year and sell them in the nearby urban markets.

Regardless of the reasons for their dropping out, among the 18 respondents 17 were found to be involved in paid work after they dropped out of school. Four of them became cattle herders, and ten were labouring with local masons, on tea stalls, at brick kilns, or on trucks and other passenger vehicles. One was working at a petrol station in a nearby town and another was a sales assistant at a local bakery. Danish, whose father's debts and sickness pulled him out of class 9, was working at a local barber shop on Rs. 30 (\$0.30) per day. These findings further imply that secondary school children who drop out then do not have the necessary qualifications or skills to engage work in that is not low skilled and low paid. Children who have dropped out of school have less education, training and skills compared to their peers who have completed school; therefore, they have fewer job opportunities in the labour market (Brekke, 2014).

In the rural areas of the district of Jhelum, child labour is not uncommon. Primary and elementary-aged children were also seen to be working at tea stalls, local restaurants, brick kilns, vehicle repair shops and in the vegetable markets.

\section{Impact of Parental Illness or Death and Loss of Family Income}

Parental death or illness limits family finances, which also affects children's school attendance (Ananga, 2011; Case \& Ardington, 2006; Kane, 2004; No et al., 2012; Woldehanna \& Hagos, 2015; Yi et al., 2012). Yi et al. (2012) found, for example, that in rural China, children who had lost their parents, or where one parent was sick or disabled, were $10.1 \%$ more likely to drop out from school. Similarly, No et al. (2012) reported that orphans are eight times more likely to drop out of school than children with living parents in rural 
Cambodia. The findings from this study are consistent with these outcomes but it is also important to note that the effects on children of parental illness or death can be more pronounced in a country like Pakistan where the social security system is underfunded and precarious.

Danish, a class 9 dropout told his story of dropping out thus:

My father worked as a labourer with local masons. He borrowed some money from family members and friends to go to abroad for work. When he arrived in a Middle Eastern country, he fell ill and returned to Pakistan. He is on bed since long due to his illness. We have no other family sources. People who loaned us money are demanding it back. I recently dropped out of class 9 because of family financial problems.

Abbas, a class 9 dropout narrated his story in the following way:

My father was a lorry driver and died in a road accident. We faced financial problems as our father was the main source of family income. I was in class 9 and had to leave school to earn money to contribute to the household income.

Muzzafar, a class 10 dropout who complained about his weak eye-sight and inability to pay the exam board fee, also reported:

My father used to work in the local cement factory as a labourer. Now he is sick and cannot work anymore. I had no other option than quitting schooling and work to contribute to the family income.

Similarly, Asif, a class 9 dropout said:

My father passed away when I was in primary school. Our maternal uncle would give us financial support for schooling. But his own children have grown up now and he is not able to support us fully. I am already weak in studies and not able to complete secondary education. My mother remains sick and she is on regular medication. I cannot see my mother dying without taking medicines. I dropped out to work and buy medicines for the sick mother.

These accounts show that parental illness and/or death has a significant impact on children and families. The most immediate impact is on children's school attendance. Furthermore, none of the children reported that their parents had ever taken out life or 
medical insurance and some said that they bought medicines for their sick parents privately, and usually took them to nearby cities to see doctors themselves, thus increasing the pressure on children to drop out of school (in order to be able to care for their parents).

The public health and formal insurance systems are underfunded and often ineffective in rural Pakistan. If the public sector is unable to provide accessible and good quality health facilities in remote villages, this pushes rural people to travel to the big cities (where they can) for better services. This not only increases treatment costs for the poor but also puts extra burdens on the public health sector in urban areas. During the fieldwork phase, it was observed that a number of private hospitals had been set up in subdivision Pind Dadan Khan. Danish and Muzzafar said during interview that they distrusted the basic public health services in the area due to the lack of doctors and medicines. Danish further reported that he took his mother to a private hospital for a medical check-up and bought prescribed medicines for her from his wages.

However, even when a family has adequate resources, parental illness or death will inevitably have an emotional impact on children (as it does all children) and may affect their performance at school, but this in and of itself does not necessarily limit their educational opportunities. This is evident from Ameer's story, a class 10 dropout who stated:

My father was a retired Navy officer. He remained ill for long time after his retirement and eventually died when I was in class 7. I had other four sisters. We had some agricultural land and a handsome family saving in bank. My father illness or death did not impact our schooling. My sisters all completed their secondary education. I dropped out of class 10 because I was more interested in becoming a religious singer.

From Ameer's statement, it is clear that his father's illness and consequent death did not

prevent his four sisters from completing secondary schooling because the family had sufficient resources to cope with the income-shock this produced. Their father's death may have affected their performance at school, but it did not cause them to cease their studies.

\section{Intersecting Push and Pull Factors}

Findings from the research showed that some of the factors determining whether children dropped out from school occurred as a result of intersecting or a combination of both push 
and pull factors. While family poverty and low income often served to pull children from school, the underlying reasons for this are often structural - lack of employment opportunities, underfunded or non existent health and social services (particularly in rural areas) and a lack of social security provision for families - and hence, from a top down perspective, often serve to push children from school. There were, however, other determinants that occurred as a result of coincidental or concurrent push and pull factors in children's lives that meant they could not or did not want continue with their education.

An example here is the location or distance to schools in rural settings and parents' (cultural) attitudes to girls' education. It was also observed during the fieldwork phase that primary schools were usually located within or near to small villages, thereby minimising travel costs for primary school aged children. Through observation and interviews with some of the fathers in the study, it became clear that many of them did not mind walking a reasonable distance to accompany their daughters to primary school, but they were reluctant to do the same for their older daughters who were in elementary and secondary school. Middle and high schools were also often further away from the smaller villages (thus, lack of appropriate education provision in rural areas can be considered a push factor for dropping out).

The study found that fathers would not allow their daughters to walk long distances to secondary schools and preferred them to be accompanied either by an adult male member of the family or to travel by a safe van. Where such transport is not available it is more likely that girls of secondary school age will drop out of school (this is confirmed in the findings from interviews with female head teachers - see Mughal, forthcoming, 2019). In addition to this, many parents have to bear the transportation costs of sending their elementary and secondary school aged girls to distant schools, which in some cases can be prohibitive. Here we can see how both cultural attitudes with respect to gender and the inaccessibility of schools in rural areas serve as intersecting dynamics that affect school dropout rates, particularly among females. An inability to afford schooling costs also limits educational opportunities for children from poor families. When parents who have limited resources and income are not able to afford the travel costs of schooling, their children are more likely to drop out of school. For example, Mateen said:

My secondary school was $4 \mathrm{~km}$ far from my locality. The daily travel cost was Rs.40. I needed minimum Rs.20 for lunch. I needed Rs.60 every day to go to school. My 
family could not afford it. Sometimes I walked $8 \mathrm{~km}$ daily to and from school. I remained hungry for the whole day because I did not have money to eat something during the break. I could not face this situation for long and decided to quit schooling.

The findings showed that some of the children who took part in the research had limited opportunities to focus on homework and school related activities at home because they had to assist with domestic chores, including helping their parents work on the land. Five respondents who had dropped out of education said that when they had been attending school they also had to help their families with cattle grazing and work on their farms when they got home or during the school holidays. Azhar, a class 9 dropout explained:

Agriculture is the main source of our family income. After I finished school, I went to the fields to bring fodder for the cattle. It was included in my daily domestic duties to prepare fodder and water the cattle in the evening. During my summer holidays, I helped my parents in harvesting.

Other children described similar experiences of helping their families by cutting crops, feeding cattle, milking buffaloes and selling milk at nearby local markets. Their stories were not very different from Azhar's. Although they stated that they would do their homework in the evenings, it appeared that most of their time after school was taken up with domestic duties.

Some of the dropped out boys stated that they played cricket and other games with their friends after they finished school and some of them also said that they did not have any domestic responsibilities to perform after school or during the summer holidays. Most of these children belonged to non-agricultural families and were free from the kind of household duties children such as Azhar described having to perform. They maintained that other factors, such as preferring to play and hang out with friends, not doing schoolwork at home as well as the absence of study support out of school all contributed to their poor educational backgrounds. Seven out of 13 respondents, for example, did not blame the teachers; they said that they had not studied hard enough in early classes. When they were asked about the reasons for this they said that they had no fear of teachers and parents and that they did not take any interest in studies at school or at home. For example, Jabbar, who dropped out of class 9, said: 
My high school was in a nearby town. I usually skipped my classes and roam across the town. I was fond of watching Indian movies. I spent my school time in watching free movies at the local tea stalls and hotels.

Another class 10 dropout, Fahad, explained:

I was passionate about breeding hunting dogs during my primary and elementary classes. I usually went to hunt rabbits with my dogs and missed classes at school. I had less interest in study and more in rabbit hunting.

The research showed that in some cases a variety, and combination of, both pull and push factors affected children's learning at school and outside of it and also contributed to their poor academic performance - when such pupils enter class 9, they are less able to show progress and as a result may drop out of school altogether. While in some respects the pull out factors here are indicated at an individual level (influenced and determined by both personal and family circumstances and pressures), push factors include a school's inability or unwillingness to implement effective strategies to ensure pupils remain engaged and are attending school regularly (that is, to completion). An example of this is where children said they dropped out through lack of interest or engagement and preferred to focus on other things.

\section{Conclusion}

While dropping out from school results in personal (individual) and social consequences (Rumberger, 2011), the circumstances leading to children dropping out need more academic attention. UNICEF (2016) estimates, on the basis of the Pakistan Demographic and Health Survey (PDHS) 2012-2013, that 3\% of girls are married by the age of 15 , and $21 \%$ by the age of 18 in Pakistan. Drawing on the perspectives of female teachers and head teachers, Mughal and Aldridge (2017) reported that $10-15 \%$ of girls marry during secondary school when they are between 14 and 16 years old in rural areas of Punjab, Pakistan. This study further evidenced that dowry and social pressures to marry sisters off at an early age also pull some poor secondary school aged boys out of school. 
Further research is needed on girls who drop out of school, and also that compares students from similar backgrounds who completed their education (without dropping out); investigating the former is challenging, particularly in rural areas, as is evidenced in the paucity of research on this topic. This is due, in the main, to prevailing cultural constraints that mean women and girls are not given a 'voice' in research - as well as in other areas of social and political life - but this does not mean that it is impossible and this should be a priority in order to ensure girls' (and women's) perspectives are not 'forever missing' from research and from public and political discourses (see, Klasen \& Wink, 2003). It would also be useful to conduct further study of the impact of early grade retention on pupils' educational advancement and capacity, ability and willingness to remain in school.

The process of children's poor educational achievement develops during primary and elementary school as a result of both push and pull school-related and household and family factors. It is evident from the findings from this study that rural areas of Pakistan are lacking in quality indicators (see, UNICEF, 2000). Poor educational background and subsequent failure in class 9 occur, in part, as a result of low quality education indicators in rural areas. Furthermore, in terms of economics, poverty at both a structural and local (family) level also increases the likelihood that children will be forced to drop out of school in order to contribute to family finances and survival. Destitute children (and families) cannot be blamed for leaving school without completing secondary education when their financial contribution to their household income becomes an absolute necessity. On the other hand, for a small number of children who are not affected by family poverty, illness or death, they may choose to withdraw (drop out) from school in order to pursue their own personal ambitions and dreams, as is also evidenced in the findings from this study.

The policy of automatic, unconditional progression (regardless of whether children pass or fail their exams) is a trade-off between more retention in early classes and poor educational outcomes in later years. At primary and elementary level, repeating a class may lead to a greater likelihood of some children dropping out; however, promoting a child who hasn't achieved grade-level outcomes unconditionally means poorer educational outcomes in later years. Monitoring quality indicators in the early grades and arranging remediation classes are some possible recommendations to overcome this problem.

Ultimately, this study evidences that both push and pull dynamics as well as intersecting, or a combination of these factors - that operate at both the structural and 
individual level -contribute to the pupil dropout phenomenon in rural Punjab. In the main, these findings demonstrate the failure of the state system to invest much needed resources in secondary education to improve the teaching and learning environment at public schools. They also reveal shortcomings in education, health and social security provision, particularly in rural areas, that mean many families cannot afford to send or ensure their children attend school. Currently, Pakistan spends $2.37 \%$ of GDP on education (UNDP, 2014). It is evident that with this limited spending on education Pakistan is less able to prevent high dropout rates or ensure that all out-of-school children return to education. If this situation remains the same, Pakistan may not be able to achieve the targets of Sustainable Development Goals (SDGs) in primary and secondary education by 2030.

\section{References}

Abuya, B. a., Onsomu, E. O., \& Moore, D. (2012). Educational challenges and diminishing family safety net faced by high-school girls in a slum residence, Nairobi, Kenya. International Journal of Educational Development, 32(1), 81-91. http://doi.org/10.1016/j.ijedudev.2011.02.012

Abuya, B., Oketch, M., \& Musyoka, P. (2013). Why do pupils dropout when education is 'free'? Explaining school dropout among the urban poor in Nairobi. Compare: A Journal of Comparative and International Education, 43(6), 740-762. http://doi.org/10.1080/03057925.2012.707458

AEPAM. (2013). Pakistan Education Statistics 2012-13. Academy of Education Planning and Management (AEPAM), Ministry of Professional and Technical Training Government of Pakistan, Islamabad.

AEPAM. (2017). Pakistan Education Statistics 2015-16. Academy of Educational Planning and Management (AEPAM), Ministry of Federal Education and Professional Training Government of Pakistan, Islamabad. Retrieved from http://library.aepam.edu.pk/Books/Pakistan Education Statistics 2015-16.pdf

Ahmed, A. Y., \& Mihiretie, D. M. (2015). Primary school teachers and parents' views on automatic promotion practices and its implications for education quality. International 
Journal of Educational Development, 43, 90-99.

http://doi.org/10.1016/j.ijedudev.2015.05.003

Al-Hroub, A. (2014). Perspectives of school dropouts' dilemma in Palestinian refugee camps in Lebanon: An ethnographic study. International Journal of Educational Development, 35, 53-66. http://doi.org/10.1016/j.ijedudev.2013.04.004

Ali, U., Hussain, L., Khan, M. A., Rafiqullah, \& Rehman, A. (2012). Determinants of dropout in primary schools of Khyber Pakhtunkhwa as perceived by the teachers. Gomal University Journal of Research, 28(1), 42-48.

Ampiah, J. G., \& Adu-Yeboah, C. (2009). Mapping the incidence of school dropouts: a case study of communities in Northern Ghana. Comparative Education, 45(2), 219-232. http://doi.org/10.1080/03050060902920625

Ananga, E. D. (2011). Typology of school dropout: The dimensions and dynamics of dropout in Ghana. International Journal of Educational Development, 31(4), 374-381. http://doi.org/10.1016/j.ijedudev.2011.01.006

Andrabi, T., Das, J., \& Khwaja, A. I. (2008). A dime a day: The possibilities and limits of private schooling in Pakistan. Comparative Education Review, 52(3), 329-355. http://doi.org/10.1086/588796

ASER-Pakistan. (2014). Annual Status of Education Report. South Asian Forum for Education Development, Islamabad, Pakistan.

ASER-Pakistan. (2017). Annual Status of Education Report (ASER). South Asian Forum for Education Development, Islamabad, Pakistan.

Battin-Pearson, S., Newcomb, M. D., Abbott, R. D., Hill, K. G., Catalano, R. F., Hawkins, J. D., \& Cata-, R. F. (2000). Predictors of early high school dropout: A test of five theories. Journal of Educational Psychology, 92(3), 568-582. http://doi.org/10.1037//0022-0663.92.3.568

Becker, G. S. (1994). Human Capital: A Theoretical and Empirical Analysis, with Special Reference to Education (3rd Revise). University of Chicago Press, Chicago, USA.

Bhutta, Z. A. (2017). Losing a generation: The impact of malnutrition. Daily DAWN. Islamabad, Pakistan. Retrieved from https://www.dawn.com/news/1296918 
Bilquees, F., \& Saqib, N. U. (2004). Drop-out rates and inter-school movements: evidence from panel data. Pakistan Institute of Development Economics, Islamabad.

BISE-Gujranwala. (2016). Secondary school (9th class) part-I examination- annual 2016. The Board of Intermediate \& Secondary Education Gujranwala, Punjab, Pakistan. Retrieved from http://www.bisegrw.com/download/GAZETTE/Gz_Ma1p16.pdf

Bjerk, D. (2012). Re-examining the impact of dropping out on criminal and labor outcomes in early adulthood. Economics of Education Review, 31(1), 110-122. http://doi.org/10.1016/j.econedurev.2011.09.003

Brekke, I. (2014). Long-term labour market consequences of dropping out of upper secondary school: minority disadvantages? Acta Sociologica, 57(1), 25-39.

Bridgeland, J. M. (2010). The new dropout challenge: bridging gaps among students, parents, and teachers. New Directions for Youth Development, 2010(127), 101-10. http://doi.org/10.1002/yd.366

Bryman, A. (2016). Social research methods (5th ed.). Oxford: Oxford University Press.

Case, A., \& Ardington, C. (2006). The impact of parental death on school outcomes: Longitudinal evidence from South Africa. Demography, 43(3), 401-420. http://doi.org/10.1353/dem.2006.0022

Chugh, S. (2011). Dropout in secondary education : A study of children living in slums of Delhi (No. NUEPA Occasional Paper 37). National University of Educational Planning and Administration, New Delhi-India.

Colclough, C., Rose, P., \& Tembon, M. (2000). Gender inequalities in primary schooling The roles of poverty and adverse cultural practice 1, 20, 5-27.

Cole, P., \& Bojang, Y. (2002). Gambia. In Educational Research Network for West and Central Africa (ERNWACA) (Ed.), A Transnational View of Basic Education : Issues of Access, Quality, and Community Participation in West and Central Africa (pp. 33-58). Academy for Educational Development, Washington, USA. Retrieved from http://pdf.usaid.gov/pdf_docs/PNACN869.pdf

Dakwa, F. E., Chiome, C., \& Chabaya, R. A. (2014). Poverty-related causes of school dropout- dilemma of the girl child in rural Zimbabwe. International Journal of 
Academic Research in Progressive Education and Development, 3(1), 233-242. http://doi.org/10.6007/IJARPED/v3-i1/792

Gibbs, B. G., \& Heaton, T. B. (2014). Drop out from primary to secondary school in Mexico: A life course perspective. International Journal of Educational Development, 36, 63-71. http://doi.org/10.1016/j.ijedudev.2013.11.005

Grissom, J. B., \& Shepard, L. A. (1989). Structural equation modeling of retention and overage effects on dropping out of school. In Paper for AERA Conference (pp. 1-22). Paper presented at the Annual Meeting of the American Educational Research Association (San Francisco, CA, March 27-31, 1989).

Hazarika, G. (2001). The sensitivity of primary school enrollment to the costs of post-primary schooling in rural Pakistan: A gender perspective. Education Economics, 9(3), 237-244. http://doi.org/10.1080/09645290110086117

Holmes, J. (2003). Measuring the determinants of school completion in Pakistan: Analysis of censoring and selection bias. Economics of Education Review, 22(3), 249-264. http://doi.org/10.1016/S0272-7757(02)00024-9

Hornby, G., \& Lafaele, R. (2011). Barriers to parental involvement in education: An explanatory model. Educational Review, 63(1), 37-52. http://doi.org/10.1080/00131911.2010.488049

Hu, F. (2012). Migration, remittances, and children's high school attendance: The case of rural China. International Journal of Educational Development, 32(3), 401-411. http://doi.org/10.1016/j.ijedudev.2011.08.001

Huisman, J., \& Smits, J. (2009). Effects of household- and district-level factors on primary school enrollment in 30 developing countries. World Development, 37(1), 179-193. http://doi.org/10.1016/j.worlddev.2008.01.007

Hunt, F. (2008). Dropping out from school: A cross country review of literature. CREATE PATHWAYS TO ACCESS Research Monograph No 16. University of Sussex.

Hussain, A., Salfi, N. A., \& Khan, T. M. (2011). Causes of students' dropout at primary level in Pakistan: An empirical study. International Journal of Humanities and Social Science, 1(12), 143-151. 
Jimerson, S. R. (2001). Meta-analysis of grade retention research : implications for practice in the 21st century. School Psychology Review, 30(3), 420-437. http://doi.org/http://dx.doi.org/10.1108/17506200710779521

Jimerson, S. R., Anderson, G. E., \& Whipple, A. D. (2002). Winning the battle and losing the war: Examining the relation between grade retention and dropping out of high school. Psychology in the Schools, 39(4), 441-457. http://doi.org/10.1002/pits.10046

Jordan, W. J., Lara, J., \& McPartland, J. M. (1996). Exploring the causes of early dropout among race-ethnic and gender groups. Youth \& Society, 28(1), 62-94.

Kane, E. (2004). Girls' education in Africa: What do we know about strategies that work? (No. 73). Africa regional educational publications. Washington, DC: World Bank. Retrieved from http://documents.worldbank.org/curated/en/862701468201600335/Girlseducation-in-A frica-What-do-we-know-about-strategies-that-work

Kaplan, J. L., \& Luck, E. C. (1977). The dropout phenomenon as a social problem. The Educational Forum, 42(1), 41-56. http://doi.org/10.1080/00131727709338151

Khan, G. A., Tahir, M., \& Shah, S. A. (2011). Gender dimensions of drop out in basic education in Pakistan : A probit analysis. European Journal of Social Sciences, 24(1), $121-133$.

Klasen, S., \& Wink, C. (2003). “Missing women”: Revisiting the debate. Feminist Economics, 9((2-3)), 263-299.

Lee, T., \& Breen, L. (2007). Young people's perceptions and experiences of leaving high school early: An exploration. Journal of Community and Applied Social Psychology, 17(5), 329-346. http://doi.org/10.1002/casp.887

Lloyd, C. B., Mete, C., \& Grant, M. J. (2009). The implications of changing educational and family circumstances for children's grade progression in rural Pakistan: 1997-2004. Economics of Education Review, 28(1), 152-160. http://doi.org/10.1016/j.econedurev.2007.04.005

Malik, A. S. (2016). Fighting malnutrition in Pakistan with a helping hand from children abroad. Retrieved from https://www.unicef.org/health/pakistan_91810.html

Motala, S., Dieltiens, V., \& Sayed, Y. (2009). Physical access to schooling in South Africa: 
Mapping dropout, repetition and age-grade progression in two districts, (April 2015), 37-41. http://doi.org/10.1080/03050060902920948

Moyi, P. (2012). Who goes to school? School enrollment patterns in Somalia. International Journal of Educational Development, 32(1), 163-171.

http://doi.org/10.1016/j.ijedudev.2010.09.002

Mughal, A. W. (2019). Investigating the issue of out-of-school children in rural Pakistan: Implications for policymakers. (Unpublished $\mathrm{PhD}$ Thesis), Loughborough University, Loughborough.

Mughal, A. W., \& Aldridge, J. (2017). Head teachers' perspectives on school drop-out in secondary schools in rural Punjab, Pakistan. Educational Studies, 53(4), 359-376. http://doi.org/10.1080/00131946.2017.1307196

Mukherjee, D., \& Das, S. (2008). Role of parental education in schooling and child labour decision: Urban India in the last decade. Social Indicators Research, 89(2), 305-322. http://doi.org/10.1007/s11205-007-9233-0

Munsaka, E. (2011). School Dropout: Are students to blame? LAP Lambert Academic Publishing.

Nath, S. R. (2008). Private supplementary tutoring among primary students in Bangladesh. Educational Studies, 34(1), 55-72. http://doi.org/10.1080/03055690701785285

National Assembly of Pakistan. (2012). The Constitution of the Islamic Republic of Pakistan. Retrieved from http://www.na.gov.pk/uploads/documents/1333523681_951.pdf

Natriello, G. (Ed.). (1987). School Dropouts: Patterns and Policies. Teachers' College Press, New York.

No, F., Sam, C., \& Hirakawa, Y. (2012). Revisiting primary school dropout in rural Cambodia. Asia Pacific Education Review, 13(4), 573-581. http://doi.org/10.1007/s12564-012-9220-2

Rosati, F. C., \& Rossi, M. (2003). Children's working hours and school enrollment: Evidence from Pakistan and Nicaragua. The World Bank Economic Review, 17(2), 283-295.

Rumberger, R. W. (2011). Dropping Out: Why Students Drop Out of High School and What 
Can be Done About it. Harvard University Press, United States of America.

Sathar, Z. A., \& Lloyd, C. B. (1994). Who gets primary schooling in Pakistan: Inequalities among and within families. The Pakistan Development Review, 33(2), 103-134.

Retrieved from http://www.jstor.org/stable/41259752

Sawada, Y. (1997). Human capital investments in Pakistan: Implications of micro evidence from rural households. The Pakistan Development Review, 36(4), 695-712.

Sawada, Y., \& Lokshin, M. (2001). Household schooling decisions in rural Pakistan. World Bank Policy Research Working Paper No.2541.

Sawada, Y., \& Lokshin, M. (2009). Obstacles to school progression in rural Pakistan: An analysis of gender and sibling rivalry using field survey data. Journal of Development Economics, 88(2), 335-347. http://doi.org/10.1016/j.jdeveco.2008.03.002

Seidu, A., \& Adzahlie-Mensah, V. (2010). Teachers and Access to Schooling in Ghana. CREATE Pathways to Access Research Monograph No. 43. University of Sussex, UK.

Senne, J. (2014). Death and schooling decisions over the short and long run in rural Madagascar. Journal of Population Economics, 27(2), 497-528.

Siddhu, G. (2011). Who makes it to secondary school? Determinants of transition to secondary schools in rural India. International Journal of Educational Development, 31(4), 394-401. http://doi.org/10.1016/j.ijedudev.2011.01.008

Smits, J., \& Huisman, J. (2013). Determinants of educational participation and gender differences in education in six Arab countries. Acta Sociologica, 56(4), 325-346. http://doi.org/10.1177/0001699313496259

Stearns, E., Moller, S., Blau, J., \& Potochnick, S. (2007). Staying back and dropping out: The relationship between grade retention and school dropout. Sociology of Education, 80(3), 210-240. http://doi.org/10.1177/003804070708000302

Stephens, D. (2000). Girls and schooling in developing countries. International Journal of Educational Development, 20(1), 1-3. http://doi.org/10.1016/S0738-0593(99)00049-8

UNDP. (2014). Human Development Report 2014- Sustaining Human Progress: Reducing Vulnerabilities and Building Resilience. The United Nations Development Programme, 
New York, USA.

UNESCO. (2017). Global educaion monitoring report 2017/18: Accountability in education:

Meeting our commitments. UNESCO, France. Retrieved from

http://unesdoc.unesco.org/images/0025/002593/259338e.pdf

UNESCO Institute for Statistics (UIS). (2017). Accountability in education: Meeting our commitments. The United Nations Educational, Scientific and Cultural Organization. Paris, France.

UNICEF. (2000). Defining quality in education. A paper presented by UNICEF at the meeting of The International Working Group on Education Florence, Italy- June 2000. Retrieved from https://www.unicef.org/education/files/QualityEducation.PDF

UNICEF. (2013). Global Initiative on Out-of-School Children: Out-of-School Children in the Balochistan, Khyber Pakhtunkhwa, Punjab and Sindh Provinces of Pakistan. UNICEF Pakistan Country Office, Islamabad. Retrieved from http://allinschool.org/

UNICEF. (2016). The state of the world's children 2016: A fair chance for every child. United Nations Children's Fund (UNICEF), New York, USA. Retrieved from https://www.unicef.org/publications/files/UNICEF_SOWC_2016.pdf

United Nations. (2016). Resolution adopted by the General Assembly on 25 September 2015: Transforming our world: the 2030 Agenda for Sustainable Development. Retrieved from http://www.un.org/ga/search/view_doc.asp?symbol=A/RES/70/1\&Lang=E

Woldehanna, T., \& Hagos, A. (2015). Economic shocks and children's dropout from primary school: Implications for education policy in Ethiopia. Africa Education Review, 12(1), 28-47.

Word Food Programme (WFP). (2017). Pakistan. Retrieved December 15, 2017, from http://www1.wfp.org/countries/pakistan

Yi, H., Zhang, L., Luo, R., Shi, Y., Mo, D., Chen, X., ... Rozelle, S. (2012). Dropping out: Why are students leaving junior high in China's poor rural areas? International Journal of Educational Development, 32(4), 555-563. http://doi.org/10.1016/j.ijedudev.2011.09.002 
